\title{
Towards a 'broadened narrow': Revaluating the change of position defence in Australian restitution law
}

DEREK M. BAYLEY

\section{Abstract}

Where a person is enriched by a mistaken payment, under the law of restitution, that person must repay the amount mistakenly provided. Yet if the payer fails to realise their mistake, and an enriched recipient, acting in good faith, beneficially relies on the payment to change his/her position, by the principles articulated in the landmark by the House of Lords decision in Lipkin Gorman (a firm) $v$ Karpnale Ltd [1991] 2 A.C. 548 , the recipient may resist repayment under the 'change of position' defence. In Australia, one year later, David Securities $v$ Commonwealth Bank of Australia (1992) 127 CLR 353 introduced a similar, but subtly different version of the change of position defence into Australian law. Whereas the UK defence undertakes broad examination of the equities of the defendant's situation in considering whether retention of the mistaken payment is justified, Australian law instead examines whether the recipient detrimentally relied upon payment. The Australian change of position defence is perhaps a narrow version, it will succeed in fewer circumstances, and will not protect a defendant who spontaneously loses payment before expending it, as no reliance on the payment would occur. Nevertheless, Australia's narrow defence is slowly broadening. This is due to indecisive treatment and unintentional ambiguity by Australia's High Court, and unconsidered application of imported legal analysis from the UK and the US, particularly of principles steeped in the language of 'inequitably' characterising the broad defence. This 'broadened narrow' change of position defence must now itself be changed, to rescue Australia's narrow defence from the brink of doctrinal obscurity. 


\section{Introduction}

In the modern history of restitution law, both the Australian and English legal systems have laboured to keep pace with other forums, due to the 'belated discovery' of the change of position defence to cases of unjust enrichment. ${ }^{1}$ Whereas the German and US legal systems have applied variants of the change of position defence for over 75 years, ${ }^{2}$ in England it was not until the landmark 1990 decision of Lipkin Gorman when the UK House of Lords finally conceded '[t]he principle is widely recognised throughout the common law world ... [and] its recognition ... is long overdue'. ${ }^{3}$ One year later, Australia's High Court also recognised the existence of the change of position defence in David Securities. ${ }^{4}$ Whereas the change of position defence in the Anglo-Australian law of restitution remains very much 'under construction', ${ }^{5}$ its comparatively recent discovery has, encouragingly, sparked a 'much fuller examination' of its definition and basic principles than ever received in many other forums, including the US Courts. ${ }^{6}$

This analysis has been a mixed blessing. Robust debate around Australia's current understanding of the change of position defence has generated disjointed academic analysis and confused application in Australian courts. This paper examines the roots of this confusion surrounding the change of position defence, offering a definition of the defence, before exploring its generally accepted bifurcation into broad and narrow conceptions. It is then argued that US and English models have permeated Australian interpretations of the defence by our courts and academics, leading to an undesirable crossbred version (the 'broadened narrow' conception). Finally, this paper concludes that the future of the change of position defence in Australia might reside in an Australian restatement delimiting the defence more concisely, similar in form, though not in substance, to the US and English restatement models.

\footnotetext{
1 American Law Institute, Restatement Third: Restitution and Unjust Enrichment (St Paul, MN American Law Institute Publishers 2011), § 65 Reporter's Note, Comment A (hereinafter 'R3RUE').

2 Florian Mächtel, 'The Defence of "Change of Position" in English and German Law of Unjust Enrichment' (2004) 5 German Law Journal 1, 24.

3 Lipkin Gorman (a firm) v Karpnale Ltd [1991] 2 A.C. 548. (hereinafter 'Lipkin Gorman'); [579]-[580] (Lord Goff).

4 David Securities v Commonwealth Bank of Australia (1992) 127 CLR 353. (hereinafter 'David Securities').

5 Mächtel, above n 2, 24.

$6 \quad R 3 R U E$, above $\mathrm{n} 1, \S 65$ Reporter's Note Comment A.
} 


\section{Defining the change of position defence}

\section{An elementary definition}

The law of restitution allows any payment causing a person to become enriched to be retained, provided there is no ground rendering the retention unjust. ${ }^{7}$ Where it is unjust, a defendant must make restitution of that enrichment. ${ }^{8}$

Such a defendant can resist repayment of the enriching sum where he/she establishes a change of position defence. ${ }^{9}$ Though the level of conceptual disagreement surrounding the defence's operation makes it difficult to establish a simple working definition, Bant's analysis suggests the following essential elements constitute a valid defence: ${ }^{10}$

- a claimant pays a defendant an amount of money under a spontaneous mistake; and

- the claimant then pursues his/her personal rights to restitution (not tortious/ contractual rights) to recover the payment; whereas

- the defendant, acting in good faith and in reliance on the security of receipt of the payment, has changed his/her position by applying the payment to their benefit.

\section{The roots of the change of position defence}

An early hint at the change of position defence appears in the 18th-century case of Moses $v$ Macferlan. ${ }^{11}$ The UK House of Lords held that a person resisting a restitutionary claim 'may defend himself by everything which [shows] that the claimant, ex aequo et bono ["from equity and conscience"] is not entitled to the whole ... demand' ${ }^{12}$ Despite this formulation, the House of Lords expressly found against the existence of an explicit change of position defence in the 1913 case of Baylis $v$ Bishop of London. ${ }^{13}$ Hamilton LJ asserted a transparent legal system did not allow resisting a claim on grounds of vague, discretionary and unprincipled justice. ${ }^{14}$ This case proved a long-running stumbling block to the legitimisation of the defence in English law.

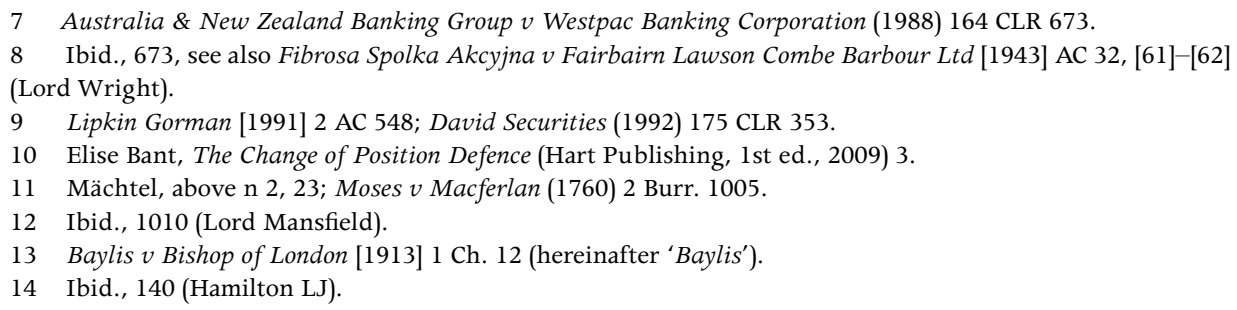


In the seminal case of Lipkin Gorman, the House of Lords overruled the Baylis prohibition, and articulated the modern starting point for examination of the primary elements of the change of position defence. ${ }^{15}$ Lord Goff's Lipkin Gorman reasoning explains the defence is available to a person whose position has so changed that it would be inequitable in all the circumstances to require him to make restitution, or alternatively to make restitution in full', ${ }^{16}$ noting also 'nothing should ... inhibit development ... on a case by case basis' ${ }^{17}$

\section{Broad and narrow approaches to the defence}

One might note that under the Lipkin Gorman formulation, the primary element of the change of position defence is inequitability, inviting a court to examine the equities of a defendant's situation, and therefore his/her liability to make restitution to the claimant on a case by case basis. This is to be contrasted with the Australian formulation in David Securities, in which the High Court identified as central to the Australian change of position defence, that '... the defendant act[s] to his/her detriment on the faith of the receipt'.

Although it is argued the judgments of Lipkin Gorman and David Securities envisaged a unified defence, ${ }^{18}$ those cases instead form what are now conventionally considered to be two strands of 'analytically distinct' reasoning, ${ }^{19}$ respectively, the broad and narrow approaches to change of position.

The divergence between the broad Lipkin Gorman approach and the narrow David Securities approach is recognised with differing emphases. Bant focuses on a reliance factor, ${ }^{20}$ claiming the broad version of the defence does not necessitate reliance on the payment, whereas the narrow version does. Birks and Barker, however, explain the split focuses upon a denial of enrichment; the broad defence does not deny enrichment, but the narrow approach does. ${ }^{21}$ These nuances are discussed further below.

15 Bant, above n 10, 125.

16 Lipkin Gorman (1991) 2 AC 548, 580 (Lord Goff).

17 Ibid.

18 Kit Barker and Ross Grantham, Unjust Enrichment (LexisNexis Butterworths, 1st ed., 2008) 431.

19 Peter Birks, Unjust Enrichment (Clarendon Press, 2nd ed., 2005) 209.

20 Bant, above $\mathrm{n} 10,4$.

21 Peter Birks, An Introduction to the Law of Restitution (Clarendon Press, revised edn, 1989), 413-414; Barker and Grantham, above n 18, 439. 


\section{The broad approach to the defence}

England's broad change of position defence, as adopted in Lipkin Gorman, would not deny a defendant becomes enriched by a mistaken payment. ${ }^{22}$ Instead, the defendant's expenditure of the mistaken payment, without notice of the claim, shifts the balance of justice between the parties, rendering it unfair or unjust for the defendant to render restitution.

The broad defence therefore prompts examination of unjust factors which outweigh the justice of allowing the claimant restitution..$^{23}$ Such unjust factors have seemingly focused on the defendant's bad faith, including undue influence, duress, and exploitation of weakness. ${ }^{24}$ The factors which the Court may consider are, however, not limitless. ${ }^{25}$ In Scottish Equitable plc $v$ Derby, ${ }^{26}$ the English Court of Appeal explained even a broad approach to the defence 'must proceed on the basis of principle, not sympathy' so as to avoid 'disintegrat[ion] into a case by case discretionary analysis of the justice of individual facts' ${ }^{27}$ Bant also considers restraining the judicial approach to be appropriate, warning against 'the threat of unbridled judicial discretion'.$^{28}$

Certain decisions of the broad approach, including the much discussed New Zealand Court of Appeal judgment in National Bank of New Zealand Ltd $v$ Waitaki International Processing (NI) Ltd appear to adjudicate proceedings on a worryingly purely subjective basis, under the guise of 'weighing the equities' ${ }^{29}$ It is not clear whether even the broad defence allows the Court licence to delve into analysis of the relative fault of the parties to discretionarily apportion loss. A perhaps more nebulous example appears in the case of Philip Collins $v$ Davis, ${ }^{30}$ where Parker J adopted a relaxed approach to the standard of proof required to be met by two musician defendants periodically overpaid. This decision is on the hand supported by Justice Edelman of the Western Australian Supreme Court, writing extrajudicially, as validly within the limits of a judge's 'idiosyncratic discretion', ${ }^{31}$ whereas the same decision is simultaneously criticised by Barker as a decision potentially undermining the 'conceptual stability of the defence' due to over-exercise of discretion. ${ }^{32}$

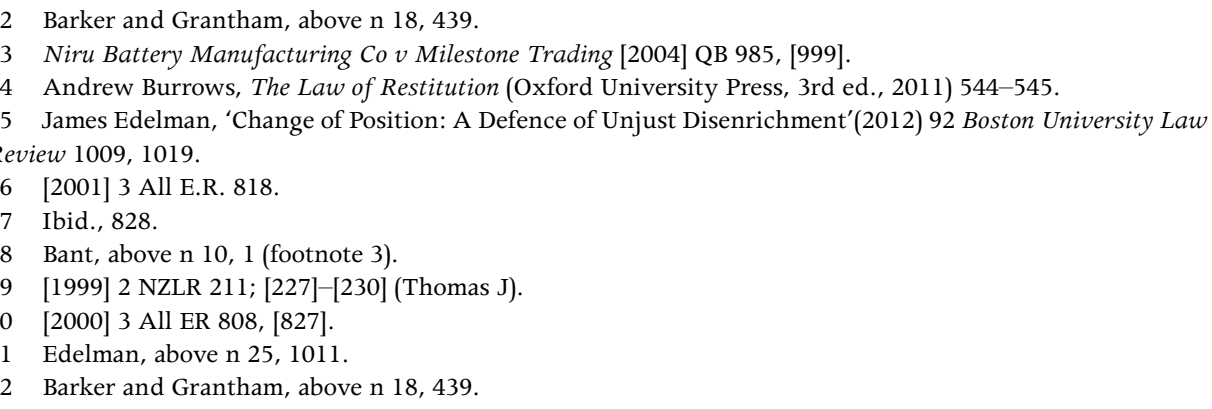


Clearly, in England's developmental phase of the broad defence, the tension between mere extension of the defence's fundamental principles and straying into discretionary analysis must be respected, balancing 'the requirement to accommodate both certainty and flexibility ... [in] novel situations' ${ }^{33}$

\section{The narrow approach to the defence}

When understanding the narrow approach to the defence, it must be first conceived of as very analytically distinct from the broad defence. ${ }^{34}$ The narrow defence requires either detrimental reliance (per Bant), or denial of enrichment of a mistaken payment (per Birks), as the foundational element of the defence's availability to a person resisting restitution. ${ }^{35}$ This, in turn, makes the narrow view to some commentators the same as estoppel without the representation. ${ }^{36}$

Consonant with the Australian High Court's approach in David Securities, Bant contends the narrow approach requires a defendant's detrimental reliance on a mistaken payment in order to establish the defence. ${ }^{37}$ Reliance would hence extend liability to defendants in cases of theft or destruction of mistaken payment before the defendant could expend the money, as they have not actively relied on the payment. ${ }^{38}$

Yet Birks considers the narrow defence operates upon a denial of enrichment, proposing that the narrow defence would not consider the defendant enriched, because the defendant's expenditure of mistakenly conferred money to their detriment causes 'subjective devaluation'. ${ }^{39}$ Subjective devaluation is caused by the vitiation of the defendant's consent in his/her choice to expend the money, without knowledge of the claimant's impending claim against him/her. This subjective devaluation causes disenrichment. ${ }^{40}$

This author suggests the two approaches are generally reconcilable: both contemplate the defendant's detriment. Bant argues detriment occurs upon the irreversibility of reliance upon the payment, whereas Birks considers detriment as the devaluation experienced by the defendant after his/her uninformed entry into expenditure.

\footnotetext{
33 W.M.C. Gummow, 'Moses v. Macferlan 250 Years On' (2011) 68 Washington \& Lee Law Review 881, 890.

34 Birks, above n 19, 209.

35 Bant, above n 10, 4.

36 See, e.g. Andrew Burrows, 'Change of Position: The View from England' (2003) 36 Loyola of Los Angeles

Law Review 803, 805.

37 Bant, above n 10, 4.

38 Ibid.

39 Birks, above n 21, 413-414.

40 Ibid.
} 
It is unnecessary to resolve this tension, as Australian courts in David Securities, Alpha Wealth and most recently in Citigroup appear to recognise the broad and narrow approaches as being split along the issue of reliance, favouring application of Bant's taxonomy. ${ }^{41}$

Thus, under the narrow approach, as requiring reliance upon the receipt of the payment, factual causation must be established by the defendant linking the reliance on payment and the defendant's subsequent expenditure. ${ }^{42}$ This is a matter of context, determined by the circumstances of both payment and receipt. ${ }^{43}$

\section{The modern Australian approach: Broadening the narrow}

This section examines the result when the broad and the narrow conceptions of the defence converge. As explored above, the narrow reliance (or disenrichment) version of the change of position defence has become strongly ingrained in Australian law, by virtue of David Securities, which focuses on detrimental reliance as the cornerstone of the defence. ${ }^{44}$ This paper submits imprecision in the subsequent reception and application of the defence has inadvertently led to a broadening of the narrow version, which has resulted in what Justice Edelman, writing academically, describes as 'lingering uncertainty' in relation to the fundamental principles of the narrow defence. ${ }^{45}$

This doctrinal uncertainty is clearly undesirable, and the fault is twofold. It lies firstly in divergences of academic opinion in unjust enrichment law, which, particularly regarding the blurred line between broad and narrow defences, contains ideas 'as mutually exclusive as they are forceful'.$^{46}$ But, more importantly, it appears academic conflict regarding the limits of broad and narrow conceptions has spilled over into the Australian judiciary's application of narrow principles, which means that the state of the law as it has been declared is also somewhat chaotic.

\footnotetext{
41 Alpha Wealth Financial Services Pty Ltd v Frankland River Olive Co Ltd [2008] WASCA 119, 203; Citygroup Pty Limited v National Australia Bank Limited [2012] NSWCA 381 (4 December 2012).

42 David Securities (1992) 127 CLR 353, [385].

43 Citigroup Pty Limited v National Australia Bank Limited [2012] NSWCA 381 (4 December 2012), [6] (Bathurst CJ, Allsop P, Meagher JA).

44 David Securities (1992) 127 CLR 353, [385].

45 Edelman, above n 25, 1015. See also Paul Walker, 'Change of Position and Restitution for Wrongs, “Ne'er the Twain Shall Meet"?' (2009) 33 Melbourne University Law Review 235, 335.

46 Ben Kremer, 'Book Review: Restatement (Third) of Restitution and Unjust Enrichment by the American Law Institute' (2012) 35 Melbourne University Law Review 1197, 1202.
} 


\section{The High Court's unintentional ambiguity}

In ANZ $v$ Westpac, ${ }^{47}$ which predates David Securities, Australia's High Court signposted its willingness to recognise the change of position defence, referring to as acceptable 'an adverse change of position by the recipient in good faith and in reliance on the payment ... which the law recognises would make ... restitution unjust ${ }^{\prime}{ }^{48}$ This approach clearly foreshadowed the narrow reliance test later favoured in David Securities.

Despite the Australian judiciary's obvious divergence from the English broad approach in David Securities, it appears that case did not deal compellingly with Lipkin Gorman. In EA Negri, ${ }^{49}$ Ross AJA reviews Lipkin Gorman's treatment by the High Court. ${ }^{50}$ He concludes that although Lipkin Gorman appears the reason for the defence's inception under Australian law, where it is considered 'a controversial statement', ${ }^{51}$ perhaps unintentionally, there remains inherent ambiguity as to its status; explaining, somewhat cryptically, 'whether Lipkin Gorman will be followed in this country remains to be seen' ${ }^{52}$

The High Court's confusion continues. As Barrett AJA notes in Citigroup, the High Court cited Lipkin Gorman in Roxborough without apparent disapproval; ${ }^{53}$ and in Farah Constructions distinguished Lipkin Gorman without suggesting its reasoning was incorrect. ${ }^{54}$

Lipkin Gorman's broad approach has, therefore, never been fully rejected in Australian law, which has allowed speculation surrounding its applicability to thrive.

\section{Preserving the narrow defence}

It is this author's contention that the narrow defence must prevail. In David Securities, in adopting a detrimental reliance approach to the change of position defence, it is clear the High Court intended to distinguish the Australian test from its English counterpart. The reasoning of ANZ $v$ Westpac and the High Court's wording of the change of position defence in David Securities, which focuses on reliance and relies explicitly on Peter Birks' narrow scholarship, indicates the High Court intended what Allsop P describes in Hills Industries as 'a narrower

\footnotetext{
47 Australia and New Zealand Banking Group Ltd $v$ Westpac Banking Corporation (166) (1988) 164 CLR, 673.

48 Ibid.

49 EA Negri Pty Ltd $v$ Technip Oceania Pty Ltd [2010] VSCA 44.

50 Ibid., [30] (Weinberg JA, Ross AJA).

51 Mason K., Carter J. \& Tolhurst G., Mason and Carter's Restitution Law in Australia, (2nd ed., 2008), [306].

52 EA Negri Pty Ltd v Technip Oceania Pty Ltd [2010] VSCA 44 [30] (Weinberg JA, Ross AJA).

53 Roxborough $v$ Rothmans of Pall Mall Australia Ltd (2001) 208 CLR 516, [66].

54 Farah Constructions Pty Ltd v Say-Dee Pty Ltd (2007) 230 CLR 89, [141]; Citigroup Pty Limited v National Australia Bank Limited [2012] NSWCA 381 (4 December 2012), [60] (Barrett AJA).
} 
or at least differently structured approach in Australia [to] England'. ${ }^{55}$ This is supported by Barrett AJA in Citigroup, who concludes Lipkin Gorman, Dextra Bank and Waitaki indicate 'a broader change of position defence than the High Court has ... recognised'.$^{56}$

Ironically, it appears the High Court, in declining to comprehensively dismiss the Lipkin Gorman formulation of the change of position defence, and by the outright endorsement of Lipkin Gorman in subsequent cases, has left the door to a broader Lipkin Gorman conception ajar. This author suggests that in David Securities, the High Court was perhaps not explicit enough in rejecting the form of the English change of position formulation, in part due its zealousness to accept and receive the defence at large in Australian law.

The High Court's clear establishment in David Securities of a different, narrower formulation to the English test must be respected, not undermined. The narrow approach was clearly envisaged by $A N Z v$ Westpac, and the broad unjust factors approach, as considered above in discussion of the broad defence, ${ }^{57}$ might be more susceptible to conceptual instability than the narrow defence, under continuous expansion and contraction due to the idiosyncratic exercise of judicial power. The narrow version, requiring objectively provable detrimental reliance, inserts a factual bulwark against a judge applying discretionary notions of what is fair and just to found acceptance of a defendant's circumstances as falling within the realms of a change of position, preventing what Edelman considers broad notions of 'palm-tree justice' ${ }^{58}$ Australia's trend towards broadening the narrow conception of the change of position defence should be halted.

\section{Legal scholarship subverting the narrow defence}

The conflation of broad and narrow has also occurred as prominent legal scholars, including the Honourable Justice William Gummow, have rallied against Australia's narrow conception of the defence. Justice Gummow postulates that our jurists engage in 'over-definition and dissection' of the defence, which 'divert[s] attention' from what he considers 'the central question; whether it would be inequitable for the claimant to require repayment ${ }^{\prime}{ }^{59}$ With respect, it appears Justice Gummow's comments place inequity in the centre of the inquiry, contradicting the true central element of the Australian defence: the David Securities test of whether there has been 'detrimental reliance' by the defendant upon the payment. 
The learned trial judge in Citigroup, Hammerschlag J, provides a contemporary example of the judiciary straying into dangerous territory applying Justice Gummow's comments. Hammerschlag J reasoned in that case that '[b]oth parties were duped ... it would lead to an inequitable result were Citibank to be made whole at the expense of $\mathrm{NAB}^{\prime}{ }^{60}$ This result, upheld by the Court of Appeal (though, importantly, readjusted within the David Securities test) appears to apply a Lipkin Gorman-style examination of the equities of the case, rather than considering relevant detrimental reliance. Such reasoning evidences a propensity towards the broadening of Australia's narrow conception.

\section{Reliance on substantive United States law}

Kremer notes many Australian cases cite the American Restatements with unelaborated approval. ${ }^{61}$ Even Australia's most contemporary restitution cases of Equuscorp and Hills Industries directly cite the R3RUE in support of legal propositions, ${ }^{62}$ and extrajudicially, Justice Gummow appears to endorse $R 3 R U E^{\prime}$ s substantive application in Australia. ${ }^{63}$

The unfettered endorsement of R3RUE threatens to broaden Australia's narrow conception on several grounds in ways repugnant to David Securities.

\section{Examination of equities, not reliance}

At $\S 65, R 3 R U E$ provides:

The right ... to restitution ... because of a benefit received is ... diminished if, after receipt of the benefit, circumstances have changed that it would be inequitable to require ... restitution.

Although Kremer considers $R 3 R U E \S 65$ 's change of position defence consistent with High Court authority, but of broader scope, ${ }^{64}$ that position appears paradoxical. Australia's narrow change of position defence seems irreconcilable with a broader scope.

\footnotetext{
60 William Co-Buchong \& Anor v Citigroup Pty Limited \& Anor [2011] NSWSC 1199, [43]-[44] (Hammerschlag J). 61 Kremer, above n 46, 1201. See, e.g. Mason v New South Wales (1959) 102 CLR 108, 144, Baumgartner $v$ Baumgartner (1987) 164 CLR 137, 153 (Toohey J); David Securities Pty Ltd v Commonwealth Bank of Australia (1992) 175 CLR 353, 370, 385 n 20 (Mason CJ, Deane, Toohey, Gaudron and McHugh JJ), 398, 399 n 69 (Brennan J); Giumelli v Giumelli (1999) 196 CLR 101, 120 n 72 (Gleeson CJ, McHugh, Gummow and Callinan JJ).

62 Equuscorp Pty Ltd v Haxton; Equuscorp Pty Ltd v Bassat; Equuscorp Pty Ltd v Cunningham's Warehouse Sales Pty Ltd [2012] HCA 7 (8 March 2012), [38]; Hills Industries Ltd v Australian Financial Services and Leasing Pty Ltd [2012] NSWCA 380.

63 Kremer, above n 46, 1215 citing Gummow, above n 33, 884-889.

64 Ibid., 1214.
} 
Fundamentally, $\S 65$ encourages US Courts to weigh the inequities of the claimant's and defendant's positions, focusing upon an 'abstract level of inequitability', ${ }^{65}$ more aligned to the UK version than Australia's version of detrimental reliance. The commentary to $\S 65$ condones idiosyncratic judicial analysis: 'if restitution would result in manifest hardship, some courts will conclude expenditure ... on ordinary living expenses makes it inequitable to require restitution', ${ }^{66}$ before citing with apparent approval such an instance in State ex rel Steger $v$ Garber. ${ }^{67}$ Firstly, Australia's defence is not construed widely enough to cover living expenses, ${ }^{68}$ and secondly, as considered above, even the breadth of the UK version does not consider inequitability an open category for discretionary analysis. ${ }^{69}$

\section{Fault}

Under $R 3 R U E$, it is recognised that the plaintiff's negligence may be relevant when the defendant has changed position. Comment $A$ to $\S 65$ explains '... restitution, like the law of torts, assigns losses on ... fault' ${ }^{70}$ Though fault has been accepted under the broad conception of the defence in Waitaki, where the Court sought to do 'justice as between the parties' such a principle overstretches the conventional broad doctrine, and any attempt to apportion loss based on relative fault criticised in the UK's case of Dextra Bank as 'hopelessly unstable', ${ }^{71}$ due perhaps to the potential undesirability of policy of allowing a defendant to keep a mistaken payment given by a claimant who may only be at fault due to their own carelessness.

For this reason, and by reason that the narrow approach does not allow an examination of relative fault, the $R 3 R U E$ 's certainly has no place to be substantively applied in developing Australia's change of position defence.

65 Edelman, above n 25, 1010

66 R3RUE, above $\mathrm{n} 1, \S 65$ Reporter's Note Comment C.

671979 WL 207282 (Ohio App. 6 Dist.).

68 Corporate Management Services v Abi-Arraj [2000] NSWSC 361, [3] (James J).

69 Edelman, above n 25, 1009.

70 R3RUE, above n 1, §65 Reporter's Note Comment A.

71 National Bank of New Zealand Ltd $v$ Waitaki International Processing (NI) Ltd [1999] 2 NZLR 21, [228]-

[229] (Thomas J); Dextra Bank \& Trust Co. v Bank of Jamaica [2002] 1 All E.R. (Comm.) 19, [40]. 
'Value received' or 'value surviving' models

$R 3 R U E$ 's $\S 65$ defence adopts the 'value received' model to enrichment, calculating the defendant's onus to disgorge with respect to the value mistakenly received, whereas Australia's approach requires restitution on the equivalent of a 'value surviving' model, calculating the restitution amount as all that remains not spent on qualifying purchases. ${ }^{72}$

The above principles demonstrate that two defences fundamentally do not correlate, and the R3RUE model has no substantive place in Australian law.

\section{Reform of the change of position defence: The case for Australia's own restatement}

The above discussion suggests serious doctrinal uncertainties in the current state of Australian scholarship, and proves ambiguity has allowed the narrow starting point in David Securities of Australian change of position defence to slowly broaden.

Though this paper cannot traverse in entirety the nature of the response needed to rectify Australia's doctrinal issues, it advances the in-principle argument that we must review the law surrounding the change of position defence with considered illustration and commentary, providing a persuasive, paramount precedent; Australia needs a restatement mechanism similar to the R3RUE.

In 2012, Andrew Burrows attempted to restate the English Law of Restitution, ${ }^{73}$ which has been endorsed by Australian academic Barker as providing 'concise, collaborative, personal, modernising and stabilising statement of the common law' $^{\prime} .^{74}$ In this way, Barker argues the ROEUE has become 'an important public platform for intellectual debate and a powerful centripetal force addressing legal fragmentation and uncertainty ${ }^{\prime}{ }^{75}$ As this paper proves, such uncertainty exists under the Australian system, arguably on an even greater scale than in England, building a strong case for development of an Australian version.

72 James Gouldkamp and Charles Mitchell, 'Denials and Defences in the Law of Unjust Enrichment' in Charles Mitchell and William Swadling (eds) The Restatement Third: Restitution and Unjust Enrichment Critical and Comparative Essays (Hart Publishing, 2013) 133, 157; Ibid.

73 Andrew Burrows, A Restatement of the English Law of Unjust Enrichment (Oxford, 1st ed., 2012) (hereinafter 'ROEUE').

74 Kit Barker, 'Centripetal Force: The Law of Unjust Enrichment Restated in England and Wales' (2014, Forthcoming) Oxford Journal of Legal Studies 1, 18, papers.ssrn.com/sol3/papers.cfm? abstract_ id $=2303720 \#$ \#.

75 Ibid., 1. 
Additionally, the most important historical roadblock to the imposition of any such restatement, either binding as statute or otherwise has been the fear of stifling the development of the common law change of position defence. ${ }^{76}$ Such a concern is no longer valid. Our common law position has matured so far as to now be in disarray. Further, as Burrows suggests, an American-style restatement is not a legislative statement, not binding on courts, merely persuasive, so its function is educative and expressive, not overriding. ${ }^{77}$

To this end, the Australian Restatement here proposed would not be a statutory encapsulation of the change of position (although it could be used as a precursor to one) in the style of New Zealand's Judicature Act 1908 or Western Australia's Property Law Act $1969 .{ }^{78}$ That said, as Bant correctly suggests, these legislative change of position defences continue to exist alongside their common law counterparts, with minimal disturbance, ${ }^{79}$ as they are interpreted cumulatively rather than consecutively with common law principles. ${ }^{80}$

\section{Conclusion}

The Australian conception of the change of position defence has received an extensive though confused examination at common law, proving a mixed blessing for practitioners and academics. In David Securities, the High Court advanced detrimental reliance as the change of position defence's central element, indicating Australia's acceptance of the narrow branch of the defence, contra to Lipkin Gorman's broad approach. Yet the narrow defence's treatment by an indecisive High Court and unconsidered application of imported legal analysis had seen the narrow defence slowly broaden, punctuated by unwelcome elements of the inequitable analysis of the broad defence. It is this trend which requires decisive correction. Drawing on the form, not substance, of existing restatement models, Australia must draft its own clear and paramount restatement framework to end confusion. Like Lord Goff's concession in Lipkin Gorman that English law had fallen behind other legal systems in the law of unjust enrichment it is now Australia's turn to accept, ${ }^{81}$ with commensurate humility, that our position is equally untenable: the time to reform the change of position defence is long overdue.

\footnotetext{
76 Law Reform Commission, Parliament of New South Wales, Report 53 - Community Law Reform Programme: Eleventh Report Restitution of Benefts Conferred Under Mistake of Law (1987) 5.41.

77 Barker, above n 74, 15.

78 Judiciature Act 1908 (NZ) s 94B; Property Law Act 1969 (WA) s 125.

79 Bant, above n 10, 251.

80 Ibid.

81 Lipkin Gorman [1991] 2 A.C. 548, [579]-[580] (Lord Goff).
} 


\section{Acknowledgments}

My sincere thanks to Professor Pauline Ridge for her insightful comments on drafts of this paper.

\section{Bibliography}

\section{A. Articles/books/reports}

American Law Institute, Restatement Third: Restitution and Unjust Enrichment (St Paul, MN American Law Institute Publishers 2011).

Bant, Elise, The Change of Position Defence (Hart Publishing, 1st ed., 2009).

Barker, Kit and Ross Grantham, Unjust Enrichment (LexisNexis Butterworths, lst ed., 2008).

Barker, Kit, 'Centripetal Force: The Law of Unjust Enrichment Restated in England and Wales' (2014, Forthcoming) Oxford Journal of Legal Studies 1, papers.ssrn.com/sol3/papers.cfm? abstract_id=2303720\#\#.

Birks, Peter, An Introduction to the Law of Restitution (Clarendon Press, revised edn, 1989).

Birks, Peter, Unjust Enrichment (Clarendon Press, 2nd ed., 2005).

Burrows, Andrew, A Restatement of the English Law of Unjust Enrichment (Oxford, 1st ed., 2012).

Burrows, Andrew, 'Change of Position: The View from England' (2003) 36 Loyola of Los Angeles Law Review 803.

Burrows, Andrew The Law of Restitution (Oxford University Press, 3rd ed., 2011).

Edelman, James, 'Change of Position: A Defence of Unjust Disenrichment' (2012) 92 Boston University Law Review 1009.

Gouldkamp, James and Mitchell, Charles, 'Denials and Defences in the Law of Unjust Enrichment' in Charles Mitchell and William Swadling (eds) The Restatement Third: Restitution and Unjust Enrichment Critical and Comparative Essays (Hart Publishing, 2013).

Gummow, W.M.C., 'Moses v. Macferlan 250 Years On' (2011) 68 Washington \& Lee Law Review 881. 
Kremer, Ben, 'Book Review: Restatement (Third) of Restitution and Unjust Enrichment by the American Law Institute' (2012) 35 Melbourne University Law Review 1197.

Law Reform Commission, Parliament of New South Wales, Report 53-Community Law Reform Programme: Eleventh Report Restitution of Benefits Conferred Under Mistake of Law (1987).

Mächtel, Florian, 'The Defence of "Change of Position" in English and German Law of Unjust Enrichment' (2004) 5 German Law Journal 1.

Mason K., Carter J. \& Tolhurst G., Mason and Carter's Restitution Law in Australia, (2nd ed., 2008).

Walker, Paul, 'Change of Position and Restitution for Wrongs, "Ne'er the Twain Shall Meet"?' (2009) 33 Melbourne University Law Review 235.

\section{B. Cases}

Alpha Wealth Financial Services Pty Ltd v Frankland River Olive Co Ltd [2008] WASCA 119.

Australia \& New Zealand Banking Group v Westpac Banking Corporation (1988) 164 CLR 673.

Baumgartner v Baumgartner (1987) 164 CLR 137.

Baylis $v$ Bishop of London [1913] 1 Ch. 12.

Citigroup Pty Limited v National Australia Bank Limited [2012] NSWCA 381.

Corporate Management Services v Abi-Arraj [2000] NSWSC 361.

David Securities v Commonwealth Bank of Australia (1992) 127 CLR 353.

Dextra Bank \& Trust Co. v Bank of Jamaica [2002] 1 All E. R. (Comm.) 19.

EA Negri Pty Ltd v Technip Oceania Pty Ltd [2010] VSCA 44.

Equuscorp Pty Ltd $v$ Haxton; Equuscorp Pty Ltd $v$ Bassat; Equuscorp Pty Ltd $v$ Cunningham's Warehouse Sales Pty Ltd [2012] HCA 7.

Farah Constructions Pty Ltd v Say-Dee Pty Ltd (2007) 230 CLR 89.

Fibrosa Spolka Akcyjna v Fairbairn Lawson Combe Barbour Ltd [1943] AC 32.

Giumelli v Giumelli (1999) 196 CLR 101. 
Hills Industries Ltd v Australian Financial Services and Leasing Pty Ltd [2012] NSWCA 380.

Lipkin Gorman (a firm) v Karpnale Ltd [1991] 2 A. C. 548.

Mason v New South Wales (1959) 102 CLR 108.

Moses v Macferlan (1760) 2 Burr. 1005.

National Bank of New Zealand Ltd $v$ Waitaki International Processing (NI) Ltd [1999] 2 NZLR 211.

Niru Battery Manufacturing Co v Milestone Trading [2004] QB 985.

Philip Collins Ltd v Davis [2000] 3 All ER 808.

Roxborough v Rothmans of Pall Mall Australia Ltd (2001) 208 CLR 516.

Scottish Equitable plc v Derby [2001] 3 All E.R. 818.

State ex Steger v Garber 1979 WL 207282 (Ohio App. 6 Dist.).

William Co-Buchong \& Anorv Citigroup Pty Limited \& Anor [2011] NSWSC 1199.

\section{Legislation}

Judicature Act 1908 (NZ).

Property Law Act 1969 (WA). 
This text is taken from The ANU Undergraduate Research Journal, Volume Six, 2014, edited by Jonathon Zapasnik and Alexandra Hogan, published 2015 by ANU eView, The Australian National University, Canberra, Australia. 